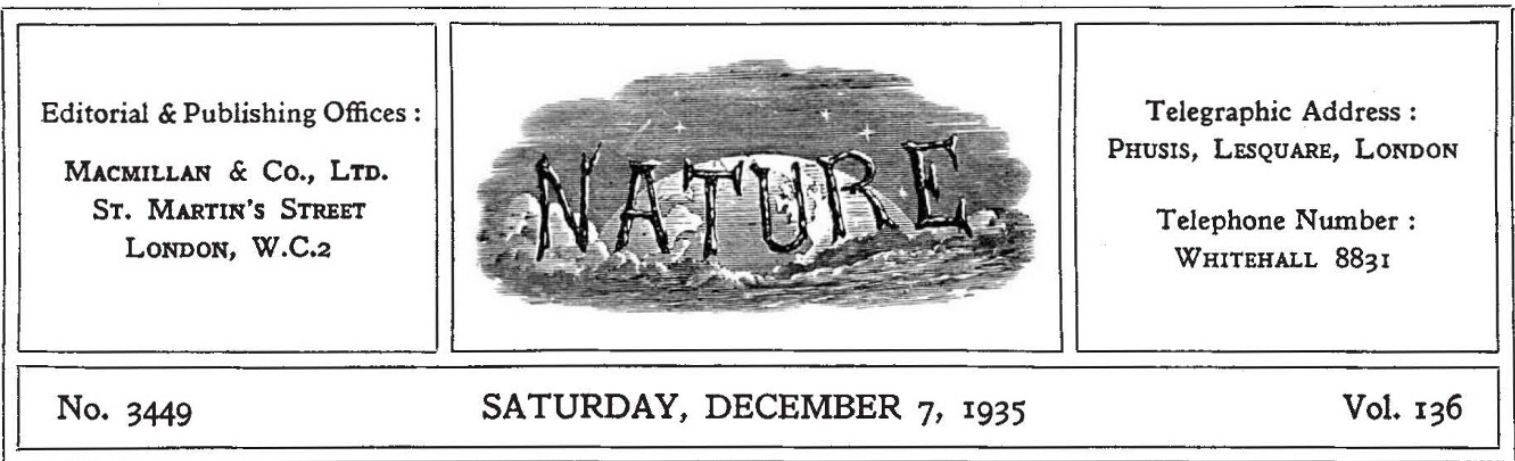

\title{
Humanistic Science
}

$I^{N}$ recent years increasing recognition has been given to the contacts of science with social problems and public affairs. Many scientific workers, particularly those of the younger generation, are no longer content to be regarded as hewers of wood and drawers of water whose special knowledge is considered to disqualify them for administrative posts. They know how science enters into every department of national life or international undertaking, and they claim to be entrusted with a reasonable share of responsible control of the forces created by them. At present these new powers seem to be out of hand in their effects upon production and also their applications to destruction. Such disappointing results are not, however, essential consequences of scientific progress, but are due to the much slower rate of advance of man's ethical and spiritual nature.

During the past few years, several leading men of science have dealt with these aspects of modern life, and over and over again we have stressed in these columns the duty of scientific workers to assist in securing intelligent recognition of scientific values in civilised communities. During the five years of his presidency of the Royal Society, and particularly in his presidential address to the British Association in 1933, Sir Frederick Gowland Hopkins has on a number of occasions referred to this wider outlook of science, in which responsibilities as citizens are combined with the pursuit of natural knowledge. In his valedictory address to the Royal Society on November 30, extracts from which appear elsewhere in this issue, he deals with the subject again, and supplements the general theme by very appropriately describing the benefits to humanity of scientific investigations of nutrition and food production.

Sir Frederick Hopkins points out that "The current interest in the subject of the national food supply and in right feeding is doubtless largely due to the awakening of the public conscience to this and other kindred social responsibilities ; but it has also been stimulated, I think, by the nature of the results which scientific studies during the last twenty years have revealed". In this department of science, at any rate, and in the control and conquest of disease, the knowledge gained has been of unqualified benefit to humanity. Whatever may be thought of modern progress, and however much some people may look back with longing eyes to the days when disease, born in filth and ignorance, stalked through the land practically unchecked, they must acknowledge that science has provided the means of reducing suffering and death due to disease, and of improving our social heritage.

This mastery over the powers-mostly microscopic-which continually tend to destroy mankind, has been obtained by scientific inquiry, the spirit of which has had a greater influence than is commonly understood. As Sir Frederick Hopkins said in his address, "History itself shows that it is wrong to deny ethical influence, even if it be indirect, to the scientific spirit. While, for example, the earlier stages of the Renaissance enriched men's minds by restoring to them the literary and philosophical heritage of antiquity, we all know that not until later, when the awakening scientific spirit demanded a courageous inquiry into the actual facts of Nature, did human thought begin its release from the shackles of authority and traditional dogma." 
The intellectual expansion brought about by the workings of this spirit, together with the sense of justice which resulted from knowledge of the existence and permanence of law in Nature, profoundly influenced human thought, and resulted in social changes which had the widest civilising effects. In spite of these ethical aspects, there are some who still regard the humanities as belonging essentially to polite scholarship or classical learning and having an antipathetic relation to science. When Greek was introduced into the curriculum of schools with the Renaissance movement of the fifteenth century, it was because the scholars of that period were eager for the new light which the language could reveal. Humanism then meant the substitution of new teaching for old, and its followers aimed at moulding the nature of man as a citizen and an active member of the State rather than at continuing the studies of doctrines relating to the next world upon which the attention of teachers had been concentrated for a thousand years.

The foundation of the Royal Society in the seventeenth century was a natural development of the revolt against scholasticism and theological authority which had for ages discouraged inde- pendent thought. The spirit of the new movement is represented by the Horatian motto, Nullius in verba, chosen by Evelyn for the Society and signifying "not bound by the words of any man"; and this intention, as the Earl of Athlone remarked at the anniversary dinner on November 30 , was expressed by an even older motto: "Prove all things ; hold fast that which is good". The object of the Society was the promotion of natural knowledge through observation and experiment as distinct from supernatural knowledge obtained through revelation. This new experimental philosophy was the method of inquiry which distinguished humanism of that epoch from medieval obscurantism, and its introduction was typical of progressive thought and action just as science is the humanism of to-day.

Science has not only emancipated human thought from the bondage of traditional authority, but also, through the concept of evolution onward and upward, has provided mankind with a new philosophy of life. It embodies, as Huxley pointed out long ago, the evolution of social ethics, and in this development through the right use of knowledge, scientific workers should take an effective part in shaping human destiny.

\section{Culture and Peoples of Ireland}

\section{Prehistoric Man in Ireland}

By Cecil P. Martin. Pp. $x i+184+11$ plates. (London: Macmillan and Co., Ltd., 1935.) $21 s$. net.

\section{A}

LL who occupy themselves seriously with - the baffling problems of prehistoric Ireland will welcome this book with open arms. It is just what they have been longing for, ever since science undertook to dispel the accumulated rubbish of charlatanism. It is not Dr. Martin's fault that the first reading of his work induces a slight sense of disappointment : it is because, with all the energy and industry which he has brought to bear upon his undertaking, the actual amount of material which he has found available is comparatively small. But he has made the best possible use of it, and has been enabled to lay a foundation which, with a little underpinning to be supplied by future discoveries, will bear the weight of years of research to come.

Ireland occupies a singular position among the countries of Europe. The Romans left her alone; they saw no advantage to be gained by occupying an island inhabited, as rightly or wrongly they believed, by cannibalistic savages. The country thus escaped Latinisation, and it afforded an extra-imperial refuge first for druids, and later for Christians, driven from their homes by persecution. The former introduced a literary tradition; the latter introduced a religion. But except for early invaders, tempted by the reputation of the auriferous gravels of the Wicklow rivers, and these refugees, the country stood aside, as the stream of culture flowed on elsewhere in the Continent. There is a biological 'lag' in the country, as is well known to biologists: these conditions produced a similar cultural lag, expressing itself in a self-centred absorption in domestic affairs, and an exaggerated appreciation of their importance. In the literature, developed first by druid refugees and afterwards by Christian scribes and teachers, there was enshrined a mass of contradictory legends, of very varying dates, about mysterious peoples called Nemedians, Fir Bolg, and so on, who had successively occupied the country: 